\title{
Loss in Productivity in Relation with Delay Analysis in Building Construction Projects
}

\author{
Er. Varma Santosh*, Prof. Emeritus. M. R. Apte** \\ * M. E Civil [C \& M] SE, MIT College, Pune. \\ ** Guide \& Professors of Civil Eng. Dept. MIT College, Pune.
}

\begin{abstract}
Schedule delays commonly occur in construction projects and often result in delay and low productivity. Several studies have proposed different schedule delay analysis methodologies. By using asplanned and as-built schedules most studies have concentrated on calculating and identifying the delay events on project but have neglected the low productivity. Loss in productivity, which is a primary cause of schedule delays, entails the completion of work at less than the planned rate of production; it is usually experienced by contractors. To solve analysis problem of schedule delays associated with loss in productivity. This study proposes a delay analysis that integrates a loss in productivity by window analysis method which primarily calculates the schedule variance between the as-planned and as-built schedules to identify the schedule impact and loss in productivity.
\end{abstract}

Key words: Loss in Productivity, Construction project, Delay analysis

\section{Introduction}

Productivity is one of the most important factors affecting the overall performance of any construction site, large or small. Schedule delays frequently occur in construction project and many studies have focused on analyzing delay values accurately and systematically from the as planned and as built schedules. Loss in productivity entails the completion of work at more than the planned rate of production, which also is termed as loss in productivity or Loss inefficiency or inefficiency. In construction project, contractor often suffer certain damages through loss in productivity caused by owner or third party. From the view point of contractor, however, loss in productivity caused by owner or third party may not be easy to identify. Loss in productivity is observed when the anticipated means, method, techniques, schedules, or work sequences of project are altered by event or circumstances beyond their control.

Resent, a study concentrated on the causes of variation order in construction project reported that some identified causes may lead to delay and loss in productivity (Enshassi et al., 2010). Calculating the impact of loss in productivity on the project schedule is important for resolving the delays. By using the as-planned and as-built schedules most previous studies have focused on calculating the impact of identified delay events on the project duration. Through a comprehensive review of delay analysis methodologies, professional project management software and commercial delay analysis software, a previous study concluded that currently available techniques and tools cannot appropriately solve the problem of schedule delays as a result of loss in productivity (Yang et al., 2010).

\section{Measurement In Delay Due To Loss In Productivity}

\section{a. LOSS IN PRODUCTIVITY \& ITS MEASUREMENT}

Productivity is commonly defined as the quantity of work produced of work output per unit of input or effort (Klanac \& Nelson 2004). Loss in productivity is usually experienced by contractor and entails the completion of work at less than the planned rate of production. There has been a considerable amount of research about the factor that causes loss in productivity common factors include acceleration (directed or constructive) adverse or unusually severe weather, the cumulative impact of multiple changes and revisions, site or work area access restrictions, site conditions, untimely approvals and responses to labour market conditions (AACE, 2004; Klanac and Nelson, 2004).

\section{b. CONVENTIONAL DELAY ANALYSIS METHOD}

Several delay analysis methods have been developed over the past two decades. Common methods include global impact, as-planned, time impact, isolated delay type, window analysis (Bordoli and Baldwin, 1998; Gothand, 2003; Hegazy and Zhange, 2005; Kim et al, 2005; Mbabzi et al, 2005; Yang and yin, 2009). These methods primarily calculate the schedule variance between the as-planned and as-built schedules 
to identify the schedule impact of delayed item on the duration of project. (Arditi and Pattanakitchanroon, 2008) reviewed several delay analysis methods and provide recommendations for selecting a suitable delay analysis method.

Similarly, (Braimah and Ndekugri, 2008) discussed the factors influencing the selection of delay analysis methodologies i.e. selecting as-planned versus as-built method, window analysis method or time impact analysis method. Key factors discussed in the two studies mentioned above include the availability of information, the time of analysis, the capabilities of methodology, the number of delaying events, the form of contract, and the time and funds available for analysis (David and Thanat, 2006). Among all types of delay analysis methods, windows based delay analysis methods are the most promising method.

\section{c. METHODS WITH CONSIDERING CONSTRUCTION PRODUCTIVITY}

In particular, the productivity method discussed in the study by (Arditi and Pattanakitchanroon, 2008) focused on calculating the amount of loss in productivity, rather than the conventional schedule delay analysis method. (Lee et al., 2005) proposed a method that coverts loss in productivity into delay duration and analysis its impact on the construction schedule delay. Their approach focused on calculating the amount of loss in productivity rather than developing a delay analysis method that would solve the delay problems caused Loss in productivity.

To integrate loss in productivity calculation and schedule delay analysis, although Lee et al method converts loss in productivity into delay duration and analysis its impact on the construction schedule delay (Lee et al., 2005), the method does not integrate loss in productivity calculation with schedule delay analysis approach. Namely, schedule analysis cannot easily utilize available methods to calculate the schedule delay impact of loss in productivity on project's schedule. This study made an assumption that all excusable and nonexcusable delay was identified earlier. Therefore, while the project has loss in productivity delays, the proposed method can allocate delay liability into the owner and the contractor separately. This study addresses how to assess and confirm the impact of a loss in productivity on a project's schedule.

\section{PROPSED APPROACH (The LOPE Method)}

Integrating concepts from the collapsed as built method (James, 2001) and the basic productivity measurement approach (Lee et al., 2005) this study proposed a delay analysis method which previously used by (Jyh-Bin Yang, Kuei-Mei, Huang, Chang-Hung, Lee, and Chui-Te Chiu., 2013) that accounts for Loss in productivity on a project. The proposed approach, referred to as the LOPE method, is elaborated below.

\section{i. Concepts and Assumptions}

Some essential concepts and assumptions are made in this study and are explained as follows.

a. For calculating the variance between baseline productivity and actual productivity, the LOPE method utilizes the actual productivity collected from activities similar to the baseline productivity for a delayed item with loss in productivity.

b. The LOPE method calculates only productivity information on each delayed item, ignoring the potential ripple effects on subsequent activities.

c. Assuming that evidence is available, the LOPE method employs the as-built schedule as a baseline schedule in the delay analysis.

d. The LOPE method can be used as a retrospective method, in cases where delays have already occurred and the work has been completed; it is unable to predict potential levels of delay for ongoing-butdelayed activities.

e. The LOPE method assumes that productivity information has been recorded and that it reflects actual project situations.

\section{ii. Analytical Procedures}

All procedure is illustrated as follows. The proposed procedures can identify whether loss in productivity problem exist or not.

Step 1: Collect the required data. i.e., Planned Schedule, As-built Schedule, Delay analysis report and construction plan. Furthermore, because the proposed method focuses on loss in productivity, it is necessary to 
collect actual productivity data and to roughly compare the actual and the planned values to verify whether a loss in productivity problem exists.

Step 2: Calculation of Planned Productivity. In this study, the LOPE method uses equation (1) to calculate average planned productivity (Prdt $\mathrm{PD}_{\mathrm{P}}$ ) value in unit of productivity per day for the impacted item, in which $\left(\mathrm{Qty} \mathrm{PD}_{\mathrm{PD}}\right.$ ) indicates the total planned quantity of work for the particular month and ( $\operatorname{Dur}_{\mathrm{PD}}$ ) is days for that particular month.

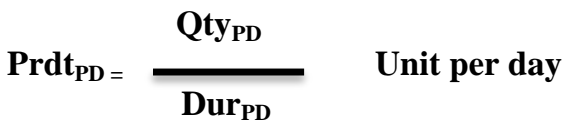

Step 3: Calculation of Actual Productivity. Similarly, equation (2) is used to calculate average actual productivity as-built $\left(\operatorname{Prdt}_{\mathrm{AL}}\right)$ value in unit of productivity per day for the impacted item, in which $\left(\mathrm{Qty}_{\mathrm{AL}}\right)$ indicates the total executed quantity of work for the particular month and (Dur $\left.{ }_{\mathrm{AL}}\right)$ is days for that particular month.

$\operatorname{Prdt}_{\mathrm{AL}}=\frac{\text { Qty }_{\mathrm{AL}}}{\text { Dur }_{\mathrm{AL}}} \quad$ Unit per day

Step 4: After obtaining the productivity values for an impacted item, the LOPE method used Eq. (3) to calculate the loss in productivity ( $\operatorname{Prdt}_{\text {Loss }}$ ). Furthermore, on the basis of the value of the loss in productivity, the delay duration for the impacted item is calculated using Eq. (4), in which ( Dur $_{\text {Prdt }}$ ) is the impacted duration caused by the loss in productivity and ( $\left(\mathrm{Qty}_{\mathrm{Loss}}\right)$ is the Loss in work quantity due to Loss in productivity. The calculation mechanism in Eq. (4) is to find the duration of completing the quantity impacted item with normal productivity.

$$
\begin{aligned}
& \operatorname{Prdt}_{\text {Loss }}=\operatorname{Prdt}_{\mathrm{PD}}-\operatorname{Prdt}_{\mathrm{AL}} \text {. Unit per day } \\
& \text { Dur }_{\text {Prdt }}=\frac{\text { Qty }_{\text {Loss }}}{\text { Prdt }_{P D}} \quad \text { in day }
\end{aligned}
$$

\section{CASE STUDY}

In order to achieve the objective, data was collected from the field practices. This case study is a multistorey seven number of public residential building with total of 514 flats at Pune [Project Phase 1 of 3]. It is 'Shell and core type of contract which means referring to the main structure and structural steel work and not inclusive of interior finishes and waterproofing. Shell and Core are type of building design is to speed up the whole design \& build process. Cores are pertaining to structures, vertical transportation systems while Shell is for facade and both are those long lead activities for the constructions.

\section{i. PROJECT DETAILS}
1. Project Name - Antheia,
2. Contractor - Joshi \& Modi Construction [JMC]
3. Type of contract 'Shell and core'.
4. Total cost of contract INR Rs. 65.73 cores.
5. Duration of contract 24 months.
6. Start Date of project 3rd of December 2012.
7. Finish Date of project December 2014.

As main project is related to shuttering, reinforcement and concrete we are focusing only the delay related to the major activities i.e. Shuttering, Reinforcement and Concrete to calculate loss in productivity. This study considers only sub-schedule of the consisting above item as given in table 1 below. It shows the delayed and non-delayed activities, respectively. 


\begin{tabular}{|c|c|c|c|c|c|c|}
\hline Sr. No. & Item & Dur. & $\begin{array}{c}\text { Planned Start } \\
\text { Date }\end{array}$ & $\begin{array}{c}\text { Planned Finish } \\
\text { Date }\end{array}$ & $\begin{array}{c}\text { Actual Finish } \\
\text { Date }\end{array}$ & $\begin{array}{c}\text { Delays in } \\
\text { Days }\end{array}$ \\
\hline $\mathbf{A}$ & Building D1 & & & & & \\
\hline 1 & Foundation/Raft & 34 & 7-Jan-13 & 10-Feb-13 & 23-Feb-13 & 13 \\
\hline 2 & Columns Upto Plinth beam & 34 & 18-Jan-13 & 21-Feb-13 & 7-Mar-13 & 14 \\
\hline 3 & Plinth Beam \& Plinth Finish & 68 & 23-Jan-13 & 03-Mar-13 & 21-Mar-13 & 18 \\
\hline 4 & Col. \& Slab of Stilt floor with plinth checking & 32 & 25-Feb-13 & 31-Mar-13 & 24-May-13 & 55 \\
\hline 5 & 2 floor Slab & 27 & 1-Apr-13 & 27-Apr-13 & 30-Jul-13 & 47 \\
\hline B & Building D2 & & & & & \\
\hline 6 & Foundation/Raft & 38 & 11-Jan-13 & 18-Feb-13 & 12-Feb-13 & 0 \\
\hline 7 & Col. Upto Plinth beam \& Plinth Beam, Finish & 48 & 22-Jan-13 & 11-Mar-13 & 24-Mar-13 & 13 \\
\hline 8 & Col. \& Slab of Stilt floor Slab part-1 & 25 & 28-Feb-13 & 24-Mar-13 & 7-Jun-13 & 75 \\
\hline 9 & Col. \& Slab of Stilt floor Slab part -2 & 25 & 7-Mar-13 & 31-Mar-13 & 20-Jun-13 & 81 \\
\hline $\mathbf{C}$ & Building D3 & & & & & \\
\hline 10 & Foundation/Raft & 45 & 1-Feb-13 & 17-Mar-13 & 11-May-13 & 55 \\
\hline 11 & Columns Upto Plinth beam & 45 & 16-Feb-13 & 1-Apr-13 & 30-Jul-13 & 120 \\
\hline $\mathbf{D}$ & Building A1 & & & & & \\
\hline 12 & Foundation/Raft & 57 & 16-Feb-13 & 13-Apr-13 & 31-Jul-13 & 130 \\
\hline $\mathbf{E}$ & Building A2 & & & & & \\
\hline 13 & Foundation/Raft & 35 & 1-Jan-00 & 20-Feb-13 & 24-Mar-13 & 31 \\
\hline 14 & Columns Upto Tie Beam & \multirow{4}{*}{53} & \multirow{4}{*}{ 29-Jan-13 } & \multirow{4}{*}{ 23-Mar-13 } & \multirow{4}{*}{ 14-Apr-13 } & \multirow{4}{*}{22} \\
\hline 15 & Tie Beams at Lower Basement & & & & & \\
\hline 16 & Filling in Tie beams & & & & & \\
\hline 17 & Col. Upto Upper Podium Slab & & & & & \\
\hline 18 & Upper Podium Floor Slab & 33 & 1-Mar-13 & 2-Apr-13 & 25-May-13 & 53 \\
\hline 19 & Columns Upto Gr Floor Slab & 33 & 16-Mar-13 & 17-Apr-13 & 10-Jun-13 & 54 \\
\hline 20 & Ground Floor Slab & 37 & 25-Mar-13 & 30-Apr-13 & 20-Jun-13 & 51 \\
\hline $\mathbf{F}$ & Building B1 & & & & & \\
\hline 21 & Foundation/Raft & 35 & 16-Feb-13 & 22-Mar-13 & 31-Jul-13 & 132 \\
\hline $\mathbf{G}$ & Building B2 & & & & & \\
\hline 22 & Foundation/Raft & 37 & 16-Jan-13 & 22-Feb-13 & 26-Mar-13 & 35 \\
\hline 23 & Tie Beams at Lower Bsmt \& filling in tie beam & 41 & 4-Feb-13 & 17-Mar-13 & 15-Apr-13 & \multirow[t]{2}{*}{16} \\
\hline 24 & Col. Upto Upper Podium Slab & 35 & 14-Feb-13 & 20-Mar-13 & 14-Apr-13 & \\
\hline 25 & Upper Podium Floor Slab & 35 & 24-Feb-13 & 20-Mar-13 & 26-May-13 & 57 \\
\hline 26 & Columns Upto Gr Floor Slab & 35 & 6-Apr-13 & 14-Apr-13 & 1-Jun-13 & 57 \\
\hline 27 & Ground Floor Slab & 40 & 16-Apr-13 & 29-Apr-13 & 10-Jun-13 & 52 \\
\hline
\end{tabular}

Table 1 Schedule information for the delayed and non-delayed activities

Table 1 shows the as planned schedule and as built schedule with result in delay for on all this activities. It is clear that except item 6 i.e. Foundation/Raft for D2 building rest of all item are delayed. As it is Shell and core type of contract concrete make major impact on the project and productivity of the project. Below Table 2 shows Planned and Executed quantity of the major item like Shuttering, Reinforcement and Concrete from January 2013 to July 2013.

\begin{tabular}{|c|c|r|r|r|r|r|r|}
\hline Sr. & Months & \multicolumn{2}{|c|}{ Shuttering in 'Sqm' } & \multicolumn{2}{|c|}{ Reinforcement in 'T' } & \multicolumn{2}{|c|}{ Concrete in 'Cum' } \\
\hline No. & Year & Planned [P] & Executed [E] & Planned [P] & $\begin{array}{c}\text { Executed } \\
{[\mathbf{E}]}\end{array}$ & Planned [P] & Executed [E] \\
\hline 1 & 13-Jan & 1786 & 0 & 145 & 0 & 1739 & 0 \\
\hline 2 & $13-\mathrm{Feb}$ & 4693 & 853 & 215 & 59 & 2100 & 862 \\
\hline 3 & 13-Mar & 10296 & 4574 & 345 & 208 & 1326 & 1758 \\
\hline 4 & 13-Apr & 16884 & 5177 & 328 & 99 & 1344 & 342 \\
\hline 5 & 13-May & 21882 & 2731 & 254 & 66 & 1529 & 372 \\
\hline 6 & 13-Jun & 24214 & 4967 & 217 & 190 & 2243 & 686 \\
\hline 7 & 13-Jul & 27609 & 4850 & 246 & 134 & 2330 & 1367 \\
\hline
\end{tabular}

Table 2 Planned and Executed quantity of Major Items

As previously stated loss in productivity will be analyzed separately for each major item i.e. Shuttering, Reinforcement and Concrete. The analysis uses of algorithms for the productivity calculation for shuttering are shown in Table 4.Table below 3 shows the loss in quantity calculation for the all three activities i.e. shuttering, reinforcement and concrete for project schedule from $1^{\text {st }}$ January 2013 to $31^{\text {st }}$ July 2013. 


\begin{tabular}{|c|c|c|c|c|}
\hline $\begin{array}{l}\text { Sr. } \\
\text { No. }\end{array}$ & $\begin{array}{l}\text { Months } \\
\text { \& Year }\end{array}$ & \multicolumn{3}{|c|}{ Loss in Quantity [Qty } \\
& & $\begin{array}{c}\text { Shuttering in 'Sqm' [P- } \\
\text { E] }\end{array}$ & $\begin{array}{c}\text { Reinforcement in ' } T \text { ' } \\
\text { [P-E] }\end{array}$ & $\begin{array}{c}\text { Concrete in 'Cum' [P- } \\
\text { E] }\end{array}$ \\
\hline 1 & $13-J a n$ & $1,786.00$ & 145 & $1,739.00$ \\
\hline 2 & 13-Feb & $3,840.00$ & 156 & $1,238.00$ \\
\hline 3 & 13-Mar & $5,722.00$ & 137 & -432 \\
\hline 4 & 13-Apr & $11,707.00$ & 229 & $1,002.00$ \\
\hline 5 & 13-May & $19,151.00$ & 188 & $1,157.00$ \\
\hline 6 & 13-Jun & $19,247.00$ & 27 & 9637.00 \\
\hline 7 & 13-Jul & $22,759.00$ & 112 & 963 \\
\hline
\end{tabular}

Table 3 Loss in Quantity for Major Items

\section{i. Calculation of Planned \& Actual Productivity}

Following the analytical procedure of Lope method we are calculating the planned [Prdt $\mathbf{P D}_{\mathbf{P D}}$ ] productivity for the shuttering, reinforcement and concrete activities referring the equation 1,2,3 and 4 as refer in analytical procedure.

$\operatorname{Prdt}_{\mathrm{PD}}=\frac{\text { Qty }_{\mathrm{PD}}}{\text { Dur }_{\mathrm{PD}}} \quad$ Unit per day

\begin{tabular}{|c|c|c|c|c|}
\hline $\begin{array}{c}\text { Sr. } \\
\text { No. }\end{array}$ & $\begin{array}{c}\text { Months } \\
\text { \& Year }\end{array}$ & Productivity for Shuttering & $\begin{array}{c}\text { Productivity for } \\
\text { Reinforcement }\end{array}$ & Productivity for Concrete \\
\hline & & Planned Prdt & $\begin{array}{c}\text { PD in 'Sqm/Day' } \\
\text { 'T/Day' }\end{array}$ & $\begin{array}{c}\text { Planned Prdt } \\
\text { 'Cum/Day' }\end{array}$ \\
\hline 1 & 13-Jan & 57.61 & 4.68 & 56.10 \\
\hline 2 & $13-\mathrm{Feb}$ & 167.61 & 7.68 & 75.00 \\
\hline 3 & 13-Mar & 332.13 & 11.13 & 42.77 \\
\hline 4 & 13-Apr & 562.80 & 10.93 & 44.80 \\
\hline 5 & 13-May & 705.87 & 8.19 & 49.32 \\
\hline 6 & 13-Jun & 807.13 & 7.23 & 74.77 \\
\hline 7 & 13-Jul & 890.61 & 7.94 & 75.16 \\
\hline
\end{tabular}

Table 4 Planned Productivity for Major Item

Similarly, calculation are made for actual $\left[\mathbf{P r d t}_{\mathrm{AL}}\right]$ productivity or the shuttering, reinforcement and concrete activities referring the equation 2 mention in Step 3.

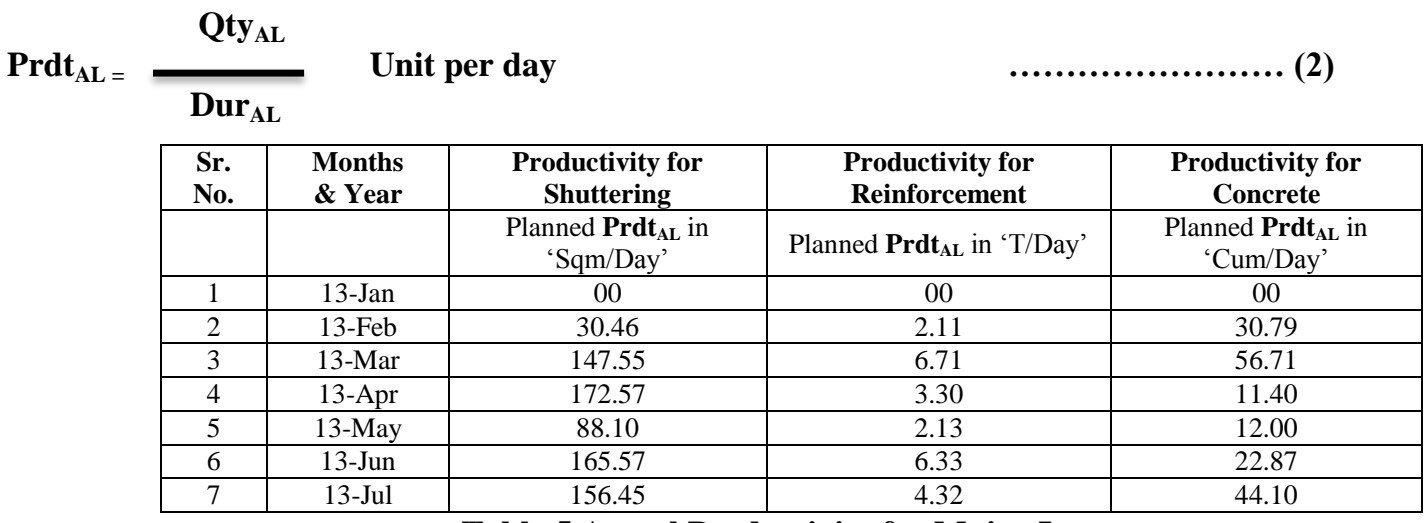

Table 5 Actual Productivity for Major Items

Chart below shows the graphical presentation of planned and actual productivity of shuttering item from $1^{\text {st }}$ of Jan 2013 to $31^{\text {st }}$ July 2013 of its project schedule. Below table show the loss quantity which is subtraction of actual quantity and planned quantity value from the above table 2 . Loss in productivity [Prdt Loss] $_{\text {s }}$ and delay [Dur Prdt] is calculated by using equation no 3 and 4 as shown in step 4 .

Prdt $_{L \text { oss }}=$ Prdt $_{\mathrm{PD}}-$ Prdt $_{\mathrm{AL}} . \quad$ Unit per day

Dur $_{\text {Prdt }}=\frac{\text { Qty }_{\text {Loss }}}{\text { Prdt }_{\text {PD }}} \quad$ in day 


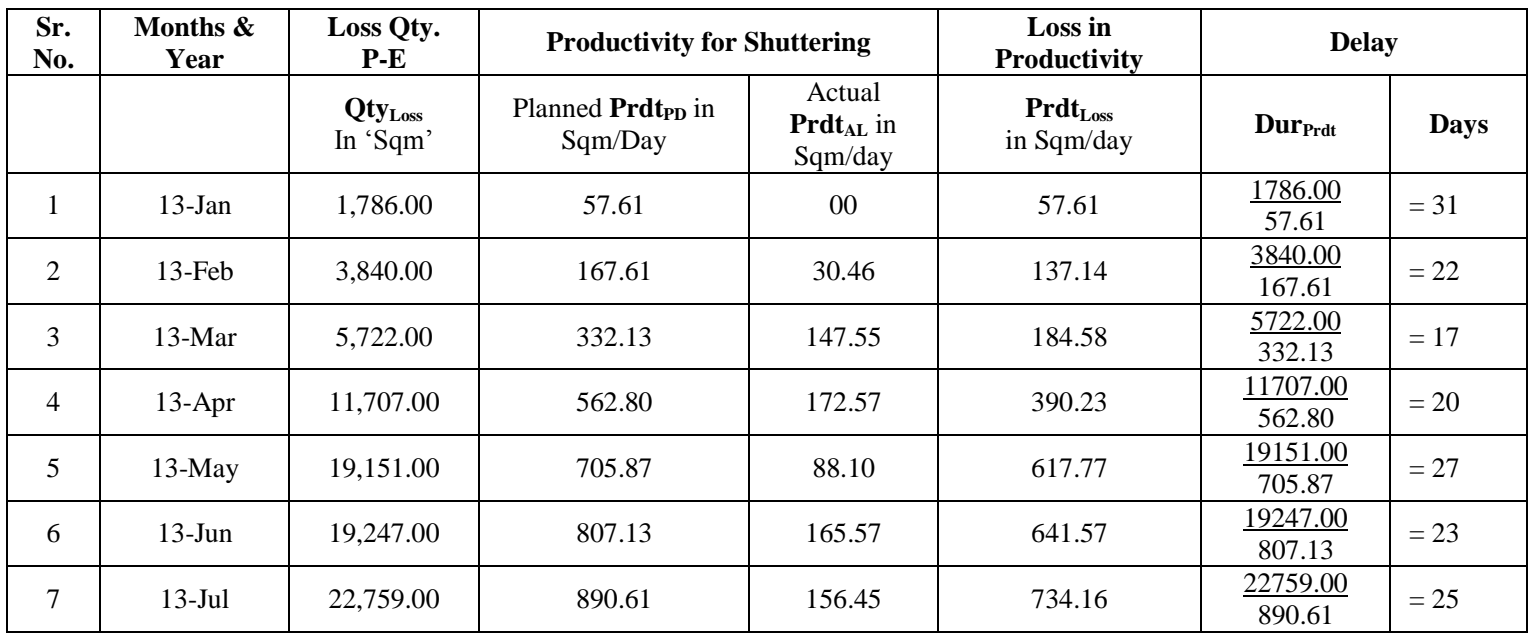

Table 6 Per month Loss in Productivity and Delay.

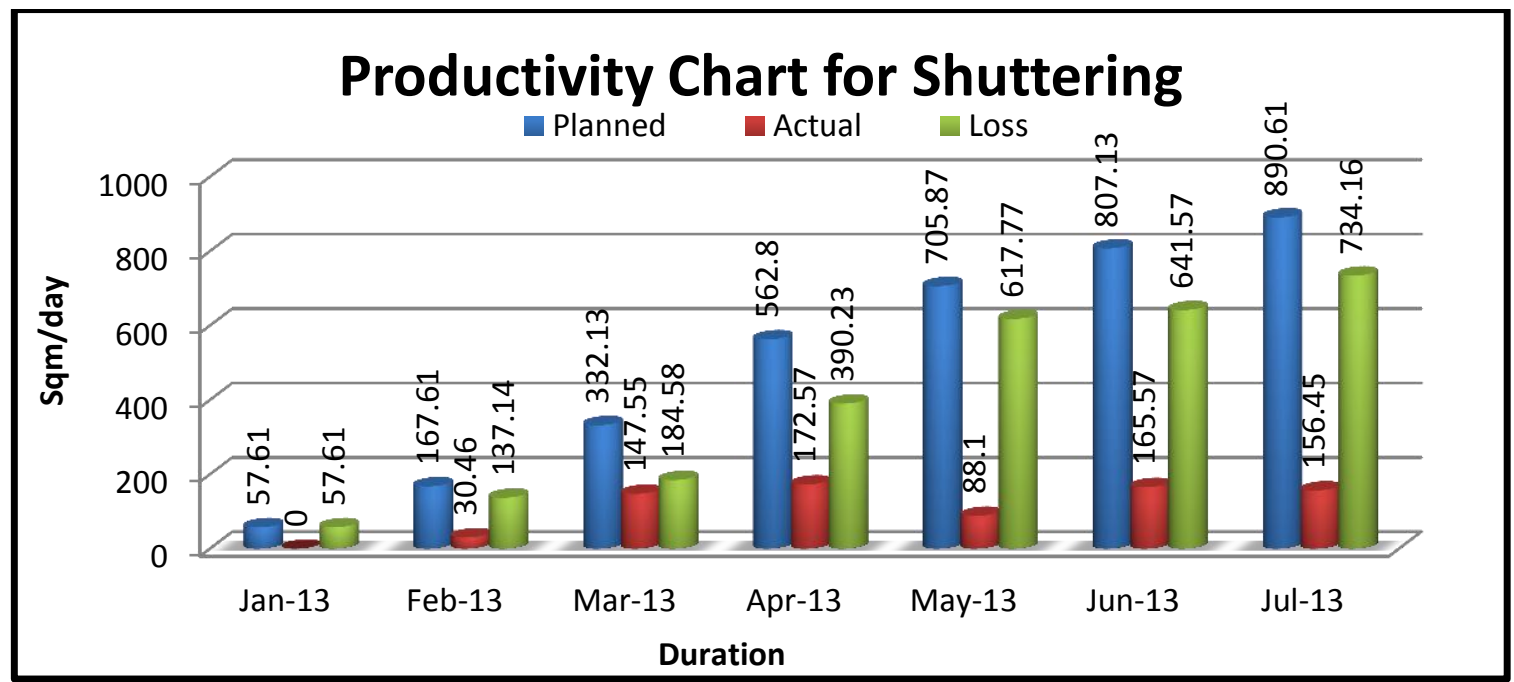

Graph 1 Productivity chart for Shuttering Item

Similarly, the analytical procedure of Lope method is used to calculating the planned [Prdt $\mathbf{P D}_{\mathbf{P D}}$ and actual $\left[\mathbf{P r d t}_{\mathbf{A L}}\right]$ productivity for the reinforcement and concrete item referring the equation 1 and 2 mention in Step 2 and 3. Loss in productivity [ $\left.\mathbf{P r d t}_{\mathbf{L o s s}}\right]$ and delay [Dur Prdt which is calculated by using equation no 3 and 4 as shown in step 4.

\begin{tabular}{|c|c|c|c|c|c|c|c|}
\hline \multirow[t]{2}{*}{$\begin{array}{l}\text { Sr. } \\
\text { No. }\end{array}$} & \multirow[t]{2}{*}{$\begin{array}{c}\text { Months \& } \\
\text { Year }\end{array}$} & \multirow{2}{*}{$\begin{array}{c}\text { Loss Qty. } \\
\text { P-E } \\
\text { Qty } \\
\text { In 'T' } \\
\end{array}$} & \multicolumn{2}{|c|}{ Productivity for Reinforcement } & \multirow{2}{*}{$\begin{array}{c}\text { Loss in } \\
\text { Productivity }^{-}\end{array}$} & \multicolumn{2}{|c|}{ Delay } \\
\hline & & & $\begin{array}{c}\text { Planned Prdt } \\
\text { T/Da in }\end{array}$ & $\begin{array}{c}\text { Actual } \text { Prdt }_{\mathrm{AL}} \text { in } \\
\text { T/day }\end{array}$ & & Dur $_{\text {Prdt }}$ & Days \\
\hline 1 & 13-Jan & 145.00 & 4.68 & 00 & 4.68 & $\frac{145.00}{4.68}$ & $=31$ \\
\hline 2 & 13-Feb & 156.00 & 7.68 & 2.11 & 5.57 & $\frac{156.00}{7.68}$ & $=20$ \\
\hline 3 & 13-Mar & 137.00 & 11.13 & 6.71 & 4.42 & $\frac{137.00}{11.13}$ & $=12$ \\
\hline 4 & 13-Apr & 229.00 & 10.93 & 3.30 & 7.63 & $\frac{229.00}{10.93}$ & $=20$ \\
\hline 5 & 13-May & 188.00 & 8.19 & 2.13 & 6.06 & $\frac{188.00}{8.19}$ & $=22$ \\
\hline 6 & 13-Jun & 27.00 & 7.23 & 6.33 & 0.90 & $\frac{27.00}{7.23}$ & $=3$ \\
\hline 7 & 13-Jul & 112.00 & 7.94 & 4.32 & 3.61 & $\frac{112.00}{7.94}$ & $=14$ \\
\hline
\end{tabular}

Table 7 Per month Loss in Productivity and Delay. 


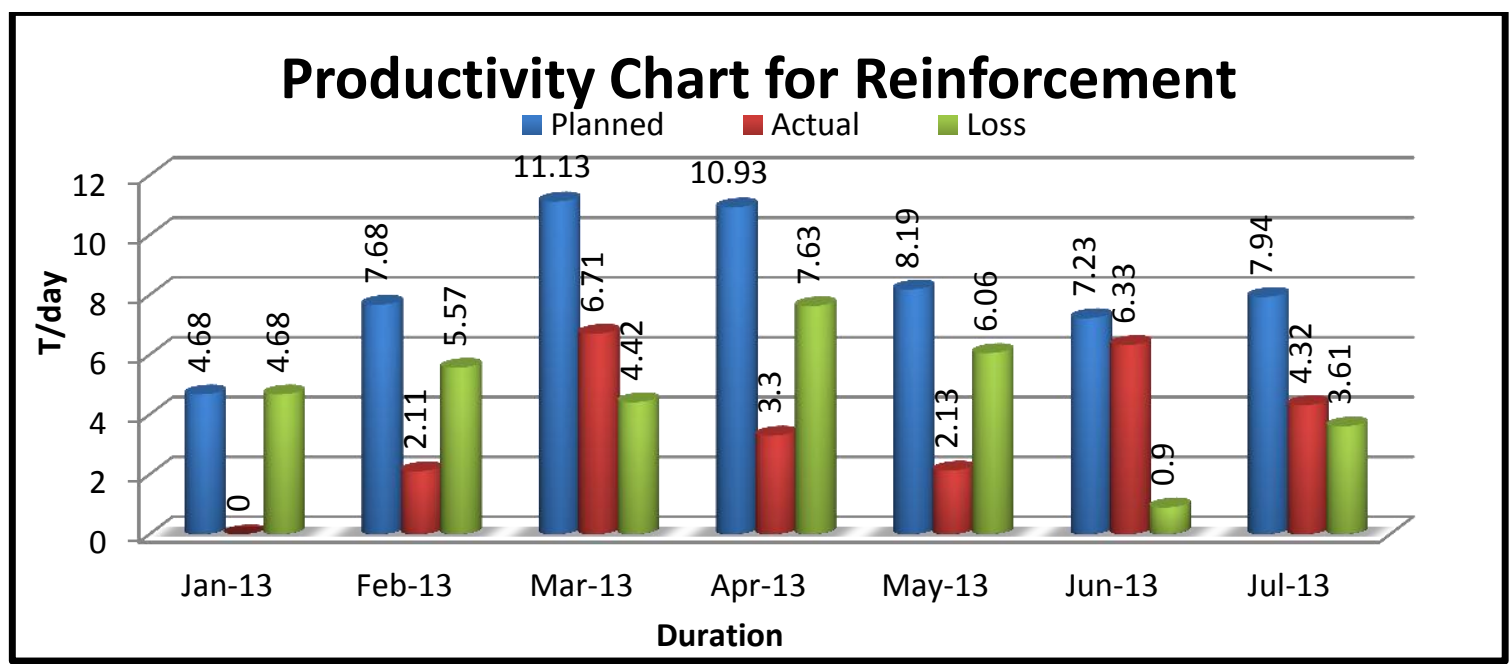

Graph 2 Productivity chart for Reinforcement Item

\begin{tabular}{|c|c|c|c|c|c|c|c|}
\hline \multirow[t]{2}{*}{$\begin{array}{l}\text { Sr. } \\
\text { No. }\end{array}$} & \multirow{2}{*}{$\begin{array}{c}\begin{array}{c}\text { Months \& } \\
\text { Year }\end{array} \\
\end{array}$} & \multirow{2}{*}{$\begin{array}{c}\text { Loss Qty. } \\
\text { P-E } \\
\text { Qty }{ }_{\text {Loss }}, \\
\text { In 'Cum' }\end{array}$} & \multicolumn{2}{|c|}{ Productivity for Concrete } & \multirow{2}{*}{$\begin{array}{c}\begin{array}{c}\text { Loss in } \\
\text { Productivity }^{\text {and }}\end{array} \\
\text { Prdt }_{\text {Loss in }} \\
\text { Cum/day }\end{array}$} & \multicolumn{2}{|c|}{ Delay } \\
\hline & & & $\begin{array}{l}\text { Planned Prdt } \\
\text { Cum/Day in }\end{array}$ & $\begin{array}{l}\text { Actual } \text { Prdt }_{\mathrm{AL}} \text { in } \\
\text { Cum/day }\end{array}$ & & Dur $_{\text {Prdt }}$ & Days \\
\hline 1 & 13-Jan & $1,739.00$ & 56.10 & 00 & 56.10 & $\frac{1739.00}{56.10}$ & $=31$ \\
\hline 2 & $13-\mathrm{Feb}$ & $1,238.00$ & 75.00 & 30.79 & 44.21 & $\frac{1238.00}{75.00}$ & $=16$ \\
\hline 3 & 13-Mar & -432.00 & 42.77 & 56.71 & -13.94 & $\frac{-432.00}{42.77}$ & $=-10$ \\
\hline 4 & 13-Apr & $1,002.00$ & 44.80 & 11.40 & 33.40 & $\frac{1002.00}{44.80}$ & $=22$ \\
\hline 5 & 13-May & $1,157.00$ & 49.32 & 12.00 & 37.32 & $\frac{1157.00}{49.32}$ & $=23$ \\
\hline 6 & 13-Jun & $1,557.00$ & 74.77 & 22.87 & 51.90 & $\frac{1557.00}{74.77}$ & $=20$ \\
\hline 7 & 13-Jul & 963.00 & 75.16 & 44.10 & 31.06 & $\frac{963.00}{75.16}$ & $=12$ \\
\hline
\end{tabular}

Table 8 Per month Loss in Productivity and Delay.

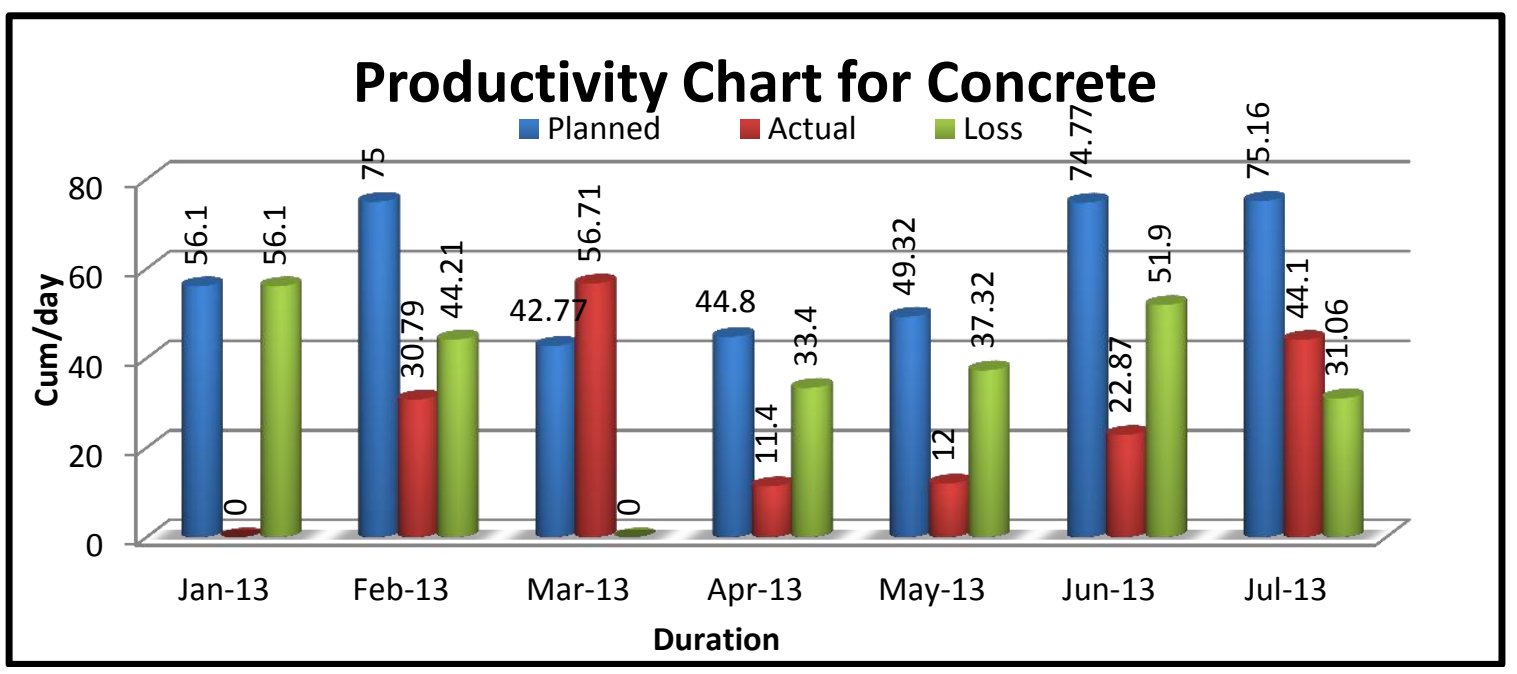

Graph 3 Productivity chart for Concrete Item

As shown in Table 3, 4 \& 5 calculated loss in productivity for item i.e. shuttering, reinforcement and concrete show that there was constant delay for all item from the month of Jan 2013 to July 2013. Further in table 6 it give the average values for all the item and calculate the total delay in days from $1^{\text {st }}$ Jan 2013 to $31^{\text {st }}$ July 2013 . 


\section{Summary}

Considering the various productivity calculation shown above for shuttering, reinforcement and concrete we are presenting here below the submission of loss in productivity of the respective item in table 6 below. The activities of shuttering, reinforcement and concrete has considerable loss in productivity of 504 $\mathrm{Sqm} / \mathrm{day}, 8.5 \mathrm{~T} / \mathrm{day}$ and $30 \mathrm{cum} / \mathrm{day}$. This loss in productivity results in loss in overall work quantities and its total impact on duration of completion time is 134 days delay.

\begin{tabular}{|c|c|c|c|c|c|c|c|}
\hline $\begin{array}{l}\text { Sr. } \\
\text { No. }\end{array}$ & Item & $\begin{array}{l}\text { Total } \\
\text { Qty. }\end{array}$ & \multicolumn{4}{|c|}{ Overall Loss in Productivity } & $\begin{array}{c}\text { Total Delayed } \\
\text { Duration }\end{array}$ \\
\hline & & & Prdt $_{\text {PLANNED }}$ & Prdt $_{\text {ACtul }}$ & Prdt $_{\text {Loss }}$ & Qty $_{\text {Loss }}$ & \\
\hline 1 & Shuttering & $\begin{array}{c}1,07,364 \\
\text { Sqm }\end{array}$ & $\begin{array}{c}504 \\
\text { Sqm/Day }\end{array}$ & $\begin{array}{c}127 \\
\text { Sqm/Day }\end{array}$ & $\begin{array}{c}377 \\
\text { Sqm/Day }\end{array}$ & $\begin{array}{l}62,205 \\
\text { Sqm }\end{array}$ & \multirow{3}{*}{134 days } \\
\hline 2 & Reinforcement & $\begin{array}{l}1,750 \\
\text { MT }\end{array}$ & $\begin{array}{c}8.5 \\
\text { MT/Day }\end{array}$ & $\begin{array}{c}4.5 \\
\text { MT/Day } \\
\end{array}$ & $\begin{array}{c}4 \\
\text { MT/Day } \\
\end{array}$ & $488 \mathrm{MT}$ & \\
\hline 3 & Concrete & $\begin{array}{c}12,611 \\
\text { Cum }\end{array}$ & $\begin{array}{c}60 \\
\text { Cum/Day } \\
\end{array}$ & $\begin{array}{c}30 \\
\text { Cum/Day } \\
\end{array}$ & $\begin{array}{c}30 \\
\text { Cum/Day }\end{array}$ & 3,420 Cum & \\
\hline
\end{tabular}

Table 6 Productivity information and analysis result.

According to the calculation of loss in productivity, the proposed method reveals that the impact of these activities has total delay of 134 days. In other words proposed method can detect and calculate the schedule impacts of delay with loss in productivity.

\section{Conclusions}

From the analysis done of major activities the outcome related to loss in productivity and overall delay incurred gives a new dimension for engineer to study the delay causes with loss in productivity. Correlation of loss in productivity with delay causes should be given more importance in the building construction trade by project management consultancy. Therefore real delay causes can be summarized as a loss in productivity problem to reflect the impact on schedules.

\section{Acknowledgements}

The authors would like to thank to my Guide Prof. Emeritus. M. R. Apte Sir, and the Civil Engineering Department of MIT College, Pune for supporting this research under the project for M.E Construction \& Management] $4^{\text {th }}$ semester. The authors are also thankful to the reviewers for their valuable suggestions through there literature.

\section{References}

[1]. AACE (2004). Estimating Loss labor productivity in construction claims, AACE International Recommended Practice No. 25R-03, Morgantown.

[2]. Arditi, D. and Pattanakitchamroon, T. (2008). "Analysis methods in time-based claims.” Journal of Construction Engineering and Management, ASCE, Vol. 134, No. 4, pp. 242-252.

[3]. Baki, M. (1999). "Delay claims management in construction-a step-bystep approach.” Cost Engineering, Vol. 41, No. 10, pp. 36-38.

[4]. Bordoli, D. W. and Baldwin, A. N. (1998). "A methodology for assessing construction project delays." Construction Management and Economics, Vol. 16, No. 3, pp. 327-337.

[5]. Braimah, N. and Ndekugri, I. (2008). "Factors influencing the selection of delay analysis methodologies." International Journal of Project Management, Vol. 26, No. 8, pp. 789-799.

[6]. David, A. and Thanat, P. (2006). "Selecting a delay analysis method in resolving construction claims." International Journal of Project Management, Vol. 24, No. 2, pp. 145-155.

[7]. Enshassi, A., Arain, F., and AlRaee, S. (2010). "Causes of variation orders in construction projects in the Gaza Strip." Journal of Civil Engineering and Management, Vol. 16, No. 4, pp. 540-551.

[8]. Gothand, K. D. (2003). "Schedule delay analysis: Modified windows approach." Cost Engineering, Vol. 45, No. 9, pp. 18-23.

[9]. Hegazy, T. and Zhang, K. H. (2005). "Daily windows delay analysis." Journal of Construction Engineering and Management, ASCE, Vol. 131, No. 5, pp. 505-512.

[10]. James, G. Z., Jr. (2001). "But-for schedules-analysis and defense.” Cost Engineering, Vol. 43, No. 8, pp. 13-17.

[11]. Jyh-Bin Yang, Kuei-Mei Huang, Chan-Hung, Lee and Chui-te Chiu. "Incorporating productivity into Delay Analysis for construction project". KSCE Journal of Civil Engineering (2014) 18(2):380-388

[12]. Klanac, G. P. and Nelson, E. L. (2004). "Trends in construction Loss in productivity claims." Journal of Professional Issues in Engineering Education and Practice, ASCE, Vol. 130, No. 3, pp. 226-236.

[13]. Lee, H. S., Ryu, H. G., Yu, J. H., and Kim, J. J. (2005). "Method for calculating schedule delay considering Loss in productivity." Journal of Construction Engineering and Management, ASCE, Vol. 131, No. 11, pp. 1147-1154.

[14]. Mbabazi, A., Hegazy, T., and Saccomanno, F. (2005). "Modified but-for method for delay analysis." Journal of Construction Engineering and Management, ASCE, Vol. 131, No. 10, pp. 1142-1144.

[15]. Yang, J. B., Huang, K. M. and Lee, C. H. (2010). "Evaluation of delay analysis methodologies on Loss in productivity in construction projects." International Symposium on Automation and Robotics in Construction 2010 (ISARC 2010), June 25-27, 2010, Bratislava, Slovakia. 